\title{
Introduction: peasants, the state and foreign direct investment in African agriculture
}

\author{
Fantu Cheru and Renu Modi
}

India, China and Brazil are striving to build their relationships with Africa in a spirit of South-South cooperation. One significant dimension of this engagement has been agriculture. The three countries have become an important source of finance, technology and infrastructure, critical for boosting the productivity of African agriculture, thereby increasing domestic food security and exports to world markets. Private enterprises and state-owned companies from the three emerging countries have started to invest in the agricultural sector of many African countries, ranging from agricultural inputs and irrigation services to farming, food processing and distribution. For China and India, however, concerns about their own domestic food security have been the main driving force for their growing engagement with African agriculture. With huge populations, growing urbanisation and a rising middle class in both countries, demand for food is expected to outstrip the capacity of local production due to diminishing arable land and serious water shortages for irrigation.

In turn, African governments have been willing to put at the disposal of foreign investors huge tracts of land for the purpose of growing commercially viable agricultural products, such as cut flowers, biofuel crops, cotton and some edible produce. These large-scale land investments by foreign investors have received mixed responses. Critical reports on the 'bonanza' reaped by foreign capital have appeared in the world media and on the websites of international organisations (Oakland Institute 2011a; 2011b; World Bank 2011a). Land rights advocacy groups have singled out investors from China, India and Brazil for criticism, alleging that their investments have resulted in unfair land acquisition, involuntary resettlement and environmental damage. They argue that small-scale farmers and pastoralists, who own land according to customary legal systems and cannot present to the authorities legally certified ownership documents, have been victimised by large-scale land acquisitions. Some of these charges are true in some instances, and the global attention they have drawn may be well deserved, given the image of Africa as a land of poverty and hunger.

The aim of this book, however, is to go beyond the current heated debate 
on 'land grabbing' and to examine the status and potential contribution of sovereign and private investors from the three emerging countries to the transformation of African agriculture. A more evidence-based understanding of foreign firms, their current and planned African footprint, as well as the potential synergies in key African markets, would add value to the wider Africa-emerging countries discourse. No country has ever made the transition to industrialisation successfully without first developing its agricultural sector, and Africa certainly needs a radical transformation of its agriculture.

The contributors to this volume take the position that foreign direct investment (FDI) can become a catalyst for modernising Africa's low-technology subsistence agriculture if it is placed within a broader national strategy on rural development that gives priority to improving the productivity of local farmers. A strong and effective development-oriented state can play a critical role in promoting fairer investment models structured to support local farmers while at the same time strengthening national technology, research and development and management capacities for pursuing efficient and sustainable agricultural development compatible with African realities. This could take the form of contract farming, whereby multinationals procure local produce, or through the extension of commercial farming hubs to enable communities to share in expensive large-scale infrastructure, such as irrigation systems. With proper regulation and state guidance, FDI can aid badly needed development rather than be exploitative.

This is not to suggest that FDI does no harm to local populations or the natural resource base, particularly in host countries with weak regulatory capacity and poor democratic governance. Much depends on local context, the investor's track record, the terms of the lease and whether these reflect the free, prior and informed consent of local landholders, and the capacity of the host government to regulate and monitor projects. The issue of land rights is just one part of the bigger puzzle of what needs to be done to bring about a successful 'agricultural revolution' in Africa. It is for this reason that we take a second look at the issue with an open mind, and let the empirical evidence speak for itself.

While land rights should remain central to the discourse on African agriculture, it would be erroneous to dismiss or downplay the potential contribution of FDI to technology transfers, skills development and the financing of vital rural infrastructure, all of which are critical for the transformation of African agriculture and for strengthening local productive capacity and employment generation. FDI's role in this field could be positive if such investments are handled properly from the start. Through detailed case studies from China, India and Brazil, the book draws lessons that can be applied to the African context. 


\section{Neocolonialism or new opportunity?}

Twenty or more years after the end of the Cold War, the debate on 'new imperialisms' and how monopoly capital influences, if not determines, the trajectory of Africa's development is back in the limelight. The renewed scholarly interest in the possible deleterious effect of neoliberal globalisation is prompted by two important developments: the scramble for African land by foreign investors, and the competing interpretations of the increasing engagement of emerging powers such as China and India with the African continent. While the debate about 'land grabbing' has primarily focused on the actions of foreign investors and their governments, little critical attention has been paid to the roles and responsibilities of African governments in facilitating largescale land acquisitions in a non-transparent way and with little consultation with local communities. Therefore, terms such as 'neocolonialism' and 'land grabbing' are inaccurate for two main reasons. First, the land is acquired on long-term leases at the invitation and with the facilitation of host country governments. Second, it is too soon to rush to conclusions, as farming by the foreign investors has only just begun. Moreover, the land may well be unused or underutilised, given that only 14 per cent of Africa's 184 million hectares of arable land is under cultivation and 21 million hectares are in a state of 'accelerated degradation', according to the United Nations' Food and Agriculture Organization. Therefore, the impetus provided by FDI in agriculture might augur well for the continent. Needless to say, however, the media hype about land rights (or the pejorative term 'land grab'), important as it is, has deflected attention from the need to examine seriously the potential contribution of FDI to unlocking the continent's productive agricultural potential.

Land has always been central to the livelihoods of the majority of Africans, who are subsistence farmers. Since independence, there have been numerous efforts by African governments and donor institutions to improve rural livelihoods by increasing the productivity of African agriculture through investment in rural infrastructure and other key inputs, land tenure reforms and improved technology, but with disappointing results. These repeated failures are often attributed, wrongly, to the refusal by the peasantry to embrace modern technology, rather than to the inappropriateness of the models themselves. Steeped in a culture of 'blaming the victims' and a misguided belief in the magic of the marketplace, proponents of large-scale industrial farming fail to acknowledge the contribution of small-scale farmers in Africa to national development. Small-scale farmers can be as productive as commercial farmers if given the same level of support. As a consequence, rural development strategies throughout Africa, by and large, have mainly benefited local elites, middle-class farmers and their foreign partners, to the detriment of the smallscale farmers in whose name these strategies were implemented. With few exceptions, agrarian reforms in post-independence Africa have not created the 
conditions for the 'emancipation' of the peasantry from exploitative patterns of production and accumulation.

The increasing engagement of foreign investors in African agriculture, particularly after the 2008 global food and energy crisis, has set off alarm bells as concern grows that the rush for more of Africa's productive land for food and biofuel production might result in the same disastrous mass displacement and super-exploitation of small-scale farmers and pastoralists that the policies of colonial and post-independence governments produced in earlier years. Growing peasant resistance in response to 'land leases' to private capital, the scale and speed of land acquisitions and the non-transparent nature of the deals warrants critical examination of the policies and strategies of African governments, and whether the expected windfall from such deals - technology transfer, employment, technical know-how and other transferrable lessons has actually materialised.

Foreign investors and host country African governments proudly declare that the main objective of large-scale land leases is to increase the productivity of African agriculture through 'green revolution'-type interventions. These, it is argued, will enable host countries to achieve food security and export high-value agricultural products to generate badly needed foreign exchange. They further argue that global demand for food and agricultural commodities offers new opportunities for African farmers to earn more through expanded exports by putting into active production much of Africa's supposedly idle land.

It is not, therefore, surprising that in the aftermath of the 2008 global food and energy crisis, the quest for more African land for food and agrofuel has accelerated on an unprecedented scale. The World Bank (2011a), the International Institute for Environment and Development (Cotula et al. 2009) and the Oakland Institute (2011a) have documented the scale of land leases around the world. An estimated 60 million hectares of land worldwide have been leased to foreign investors to grow either food for consumption in the investors' own countries or to produce agrofuels to offset the rising cost of oil. According to current reports, two-thirds of the land acquired was in Africa. It is difficult to ascertain the exact scale of these land deals since the actual documents are kept secret.

\section{The glass is neither 'half full' nor 'half empty': the need for pragmatism}

Accumulation by dispossession has been a central feature of agrarian relations under colonial and postcolonial development strategies. The African peasantry has borne the negative consequences of the misguided and topdown rural development policies of post-independence governments as they attempted to 'mimic' the industrialisation experience of Western Europe and North America. This inherited ideology viewed peasant agriculture as backward 
and traditional and sought to transform it in the image of Western mechanised farming, largely oriented towards the global market. It was believed that the modernisation of African agriculture, if successful, could serve as the foundation for the continent's industrialisation dream. In pursuing this strategy, millions of peasants were forcibly displaced from their traditional grazing areas to make way for export agriculture. With higher foreign exchange earnings from agricultural commodity exports, it was believed that both the security needs of African governments and their drive towards industrialisation could be achieved. On both counts, however, African governments failed miserably.

As Africa entered the 1980s, not only were economies in a shambles, but food production had declined and half the continent faced chronic famine as a result of bad weather and declining productivity. The failure of export-led agricultural development meant that African countries were unable to feed themselves, and the drawbacks of undue emphasis on commercial farming became increasingly clear as repeated famines claimed the lives of millions of people. Soon after, the narrative on African agriculture changed, with the emphasis shifting to the central role of small-scale farmers in achieving family food security. National governments, with the support of donors, changed course by directing policy towards these smallholder farmers.

Almost two decades later, both national governments and the very donors who supported the small-scale farmer strategy are having second thoughts. The 'modernisation craze' is back in the limelight. The global commodity crisis of 2007-08, during which there were severe shortages on the world food market accompanied by a dramatic rise in grain prices, provided the impetus for both private and sovereign investors to rush to so-called 'land-rich' countries in Africa and elsewhere to acquire land for growing food and biofuel crops for export. However, these large-scale acquisitions are contested on the grounds that they violate the land rights of local inhabitants and that the lease arrangements have been made without consulting them.

\section{Scope of the book}

The book is divided into five sections. In the first, the approach to the research is elaborated, and the contemporary and historical debates on the role of foreign capital in Africa's agricultural development are explained. In Chapter 1, Fantu Cheru, Renu Modi and Sanusha Naidu outline the parameters that should be used to measure the contribution of FDI to host countries' development. They note that the exclusive focus on the role of foreign investors in land acquisitions misses or underestimates the potential of FDI to support technology transfers, skills development and asset creation. In Chapter 2, Sam Moyo provides a historical account of the role of foreign capital in Southern Africa, suggesting that it has been associated with what he refers to as 'accumulation by dispossession'. He warns that if African governments fail 
to put in place appropriate checks and balances, FDI in African agriculture could perpetuate these disastrous results, namely the destruction of the livelihoods of millions of Africa's smallholder farmers and the unsustainable use of land and water resources.

The second section examines the scope and content of India's private and public sector engagement in African agriculture. It must be stated at the outset that the two Indian contributors present an analysis that in many ways mirrors the official views of the Indian government and the Indian private sector. In its public diplomacy, the government of India has tried to project itself as a 'rising power' whose time has come to shape global development in a positive direction, particularly in Africa and South Asia, through its aid, investment and technical assistance programmes. This posturing often does not pay sufficient attention to the more complex and controversial elements of Indian agriculture domestically and Indian investment abroad that have been raised convincingly by Dessalegn Rahmato and Rick Rowden in this volume.

In Chapter 3, India's former ambassador to Ethiopia, Gurjit Singh, outlines the policies and strategies of the government of India for strengthening economic relations with Africa, and discusses the instruments currently in place to assist Indian entrepreneurs in expanding their investments in Africa. Singh states that India has no ulterior motives other than to help African countries tackle the crisis in agriculture through aid, technical assistance and lines of credit to encourage Indian private sector operators to invest in Africa. This view is corroborated by Modi, who in Chapter 4 examines Indian private sector investments in African agriculture and the role the Export-Import Bank of India plays in financing such investments. Both authors present India as a 'rising power' committed to helping African countries escape poverty and underdevelopment, asserting that Indian private sector investment and official aid are helping African partner countries build the policy and institutional foundations necessary for reversing the productivity decline in agriculture, generate jobs, reduce poverty and ensure food security on the continent.

Beneath their invocation of the principles of mutual respect, mutual benefits and non-interference as central elements in India-Africa relations, however, others might argue that their analysis contains elements of the same patronising views often associated with Western donors, who claim that only outsiders can put the African continent on a transformative path. In Chapter 4, Modi acknowledges briefly the chronic problem of widespread hunger and malnutrition, the large number of farmer suicides, the deeply alarming decline of the water table and other environmental problems that characterise Indian agriculture today. A detailed discussion of the shortcomings of the agricultural sector in India has not been undertaken, as it is beyond the scope of the present project. Nevertheless, both Singh and Modi present evidence to confirm the commercial nature of contemporary India-Africa relations in 
the field of agriculture, which has the potential to produce the same destructive environmental and social outcomes if African governments do not take precautionary measures.

In fact, the governments of Africa have the advantage of hindsight. They can avoid the massive social and environmental pitfalls of the green revolution in particular and of the Indian agricultural sector in general. While incorporating the success stories of the green revolution, safeguards need to be established and preventive measures need to be adopted by countries in Africa to deal with the adverse consequences that have been faced by the Indian agricultural sector. Section two of the book aims to provide a comprehensive picture of India's engagement in the agricultural sector of Africa and therefore includes various versions of the same story.

In pursuance of this objective, the first two chapters of this segment provide important insight into the Indian government's and the corporate sector's perspectives vis-à-vis investments in African agriculture. The upbeat and positive assessment presented by Singh and Modi on India's engagement in African agriculture is balanced by Rahmato (Chapter 5) and Rowden (Chapter 6), who critically examine large-scale land acquisition by Indian companies from a land rights perspective. Focusing on an Indian company, Karuturi Global, and its acquisition of 300,ooo hectares of land in the Gambella region of Ethiopia, Rahmato examines the consequences of a shift from small-scale to large-scale and foreign-dominated production for agrarian relations in Ethiopia as well as for the environment and for biodiversity. In Chapter 6, Rowden, based on a content analysis of the lease agreements of five Indian investors in Ethiopia, arrives at the same conclusion. Without passing judgement, both contributors point out one critical challenge: how to reconcile the need for more private investment in land with the urgent need to protect the land rights of smallscale farmers and pastoralists. The editors address this strategic challenge in the concluding chapter.

Brazil's strategy to transform African agriculture is the focus of section three. In Chapter 7, Thomas Cooper Patriota and Francesco Maria Pierri examine the increasing commercial ties, including FDI, between Brazilian multinationals and a number of African countries. While current initiatives are small compared with Chinese and Indian investments in Africa, Brazil pursues more structured and multi-sectoral cooperation in agriculture and sustainable rural development that could potentially bring enormous benefit to Africa. These initiatives include a more systematic approach to sharing tropical agricultural technologies provided through Embrapa (Empresa Brasileira de Pesquisa Agropecuária), a state-owned company credited with Brazil's agricultural boom in the last decade; a concessional financing platform for importing Brazilian farm machinery; and a knowledge-sharing platform that offers about four decades of Embrapa expertise aimed at poor smallholder farmers. In Chapter 8, Kai 
Thaler examines Brazil's investment in the production of biofuel feedstock in Mozambique and criticises the prioritisation of biofuel production in a country where the vast majority of the population experiences high levels of food insecurity. He questions whether the emphasis on biofuel production can be reconciled with enhancing food security and furthering the government's goal of poverty reduction.

In Chapter 9, Alexandra Arkhangelskaya and Albert Khamatshin discuss the contributions made to agriculture in Africa through IBSA, a trilateral forum comprising India, Brazil and South Africa. Although the resources of IBSA are minuscule, it complements the bilateral strategies of Brazil and India to improve agricultural productivity in order to reduce poverty and enhance food security in the least developed countries. One such country is Guinea-Bissau, where targeted projects are increasing the cultivation of rice through improved lowland rehabilitation, water management and animal husbandry.

The fourth section focuses exclusively on China's engagement with African agriculture within the framework of the Forum on China-Africa Cooperation (FOCAC). In Chapter 10, Simon Freemantle and Jeremy Stevens describe the domestic dimensions of China's growing interest in investing in the agricultural sector in Africa and other developing regions. The authors note that China's role in land acquisition in Africa has so far been minimal in comparison with India and Middle Eastern investors. Indeed, the authors point out that China's 20-year food security strategy, unveiled in 2008 by the National Development and Reform Commission, did not include foreign land acquisition as a pivotal feature, with the exception of soya bean production in Brazil. In future, however, foreign land acquisitions will certainly become part and parcel of China's food security strategy for two compelling reasons. With increasing incomes among average Chinese consumers, demand for agricultural commodities is likely to grow during the coming decades and this demand cannot be met through domestic production alone because of diminishing local resources, principally arable land and irrigable water.

In Chapter 11, Xiuli Xu and Xiaoyun Li, professors at the China Agricultural University, discuss in detail China's post-1979 agriculture-led development strategy that is credited with the country's unprecedented scale of poverty reduction over the past 25 years. The authors persuasively argue that China's success was the outcome of strong incentives provided by government through land tenure reform and pricing policies, coupled with major public investment in infrastructure (roads, irrigation and energy), research into seeds and soils, greatly expanded fertiliser production and use, farmer education and, crucially, off-farm employment through local enterprise development. Central to the Chinese approach, from which Africa can learn much, is the existence of a strong, effective development state with a long-term vision. The authors conclude that China's approach has been pragmatic and is based on learn- 
ing from others, adapting to local circumstances, scaling up what works and abandoning unsuccessful experiments, a lesson that is instructive for African countries.

In the final chapter (Chapter 12), the editors, based on the evidence presented by the contributors, conclude that the actual impact of Chinese, Indian and Brazilian private and sovereign investment in African agriculture has been positive in the short and medium term thanks to enhanced technological transfers, skills development, provision of infrastructure and finance, and the creation of the conditions needed to unleash Africa's agricultural productivity. At the same time, the editors highlight two important problems that will ultimately determine the effectiveness of the current approach to South-South agricultural cooperation. The first relates to the sensitive issue of the land rights of local communities affected by large-scale land investments. The second concerns the downstream effect of technology and infrastructure designed for commercial agriculture on the surrounding communities, and how to ensure that smallholders also benefit from these costly rural infrastructure networks.

The issue of land rights goes beyond policies on agricultural development. It is part and parcel of the unfinished governance agenda in Africa. That said, a more transparent governance framework on property relations that protects the land rights of local communities should be a precondition for attracting FDI into the agricultural sector. This would entail the development of policies that delineate the roles and responsibilities of the state, the peasantry and domestic and foreign capital in a consultative and transparent way. The editors question the relevance and legitimacy of international efforts to introduce voluntary guidelines on FDI in the agricultural sector by arguing that voluntary guidelines are poor substitutes for strong and transparent national laws and regulations governing the operation of FDI in African agriculture. They insist that a robust and nationally owned institutional framework governing such FDI in terms of technology transfer, skills development, asset creation and compliance with international labour and environmental standards is a necessary precondition for monitoring compliance by foreign and domestic investors and for evaluating their overall contribution to the transformation of African agriculture.

\section{Changing course: harnessing foreign direct investment to transform African agriculture}

There is no doubt that Africa's agriculture is in need of major transformation, given the sector's contribution to the growth of gross domestic product, employment and livelihoods. This urgent need has been acknowledged by the Comprehensive Africa Agriculture Development Programme of the African Union, especially in the current context of global food price volatility and of low food stocks, both of which have had a particular impact on the marginalised 
and the poor. Agricultural research, supportive rural infrastructure, adequate development finance, skilled personnel and strong institutions have remained relatively underdeveloped. National budgets devoted to the agricultural sector remain low and few African countries have a coherent strategy to mobilise resources domestically. Given the urgency of raising agricultural productivity on the continent, attracting FDI should be a priority for African governments, since such investment can play a critical role in addressing longstanding constraints.

At the same time, initial efforts by a handful of African governments to attract FDI to the agricultural sector have met with scepticism. Activist civil society organisations point out that FDI in African agriculture has largely contributed to the displacement of subsistence farmers and pastoralists from the land they depend on and that most of these investments are directed at producing non-food items, such as cut flowers and biofuel crops, and not necessarily food for local consumption (see Chapter 6). To some degree, these criticisms have made important contributions by highlighting the issue of land rights and the lack of transparency in decision making in large-scale land deals. Where the critics go wrong, however, is in apportioning blame to the foreign investors. One of the major problems has been the failure of host governments to take decisions on land leases in light of a broader strategy on rural development. While corruption remains a problem, many African countries lack the technical and human resources to monitor and regulate large-scale agricultural projects.

Not all land deals, whether with foreign or domestic investors, are implicated in the dispossession and wanton destruction of the livelihoods of local communities. If undertaken with proper due diligence, large-scale land investments can create opportunities in food-deficit African countries. Such investments could improve the local infrastructure and economy, ensure technology transfers and provide long-term employment. The real focus of the critics should be on the role and responsibilities of national governments in establishing the ground rules for FDI in African agriculture, and in ensuring that they get the best out of any investment deals. Africa's need for development finance, technology and human capital development is huge and cannot be met with local resources alone. Attracting FDI to the agricultural sector is, therefore, critical, as long as it is within the context of a long-term national development vision.

The exclusive focus on 'land rights' or 'land grab' unfortunately leaves little room for a thorough evaluation of the potential contribution of FDI to asset creation through capacity building and skills development in farming, enhanced transfers of appropriate technology and the provision of finance for infrastructure development - all of which are critical to a successful agrarian revolution in Africa. Moreover, pejoratively equating all FDI in agriculture with 'land grabbing' could potentially stop investment altogether as potential foreign 
investors try to avoid reputational and financial risks. The role of a vigilant civil society and the media is indispensable in holding national governments accountable so that the benefits of international investments are channelled to strengthen the productivity of small-scale farmers, promote value addition through technology transfer and innovation, expand opportunities for non-farm employment by diversifying the rural economy, and improve competitiveness and economic transformation. This approach demands high and sustained levels of investment in key public infrastructure (such as rural roads and irrigation), in agricultural research and new technology, and in input-related industries in areas such as fertilisers and seeds - all of which can be provided sufficiently by China, India and Brazil. 